Available online at GSC Online Press Directory

GSC Biological and Pharmaceutical Sciences

e-ISSN: 2581-3250, CODEN (USA): GBPSC2

(REVIEW ARTICLE)

\title{
Plant toxins: alkaloids and their toxicities
}

\author{
Kamarul Zaman Munirah Adibah and Mohamad Azzeme Azzreena* \\ Department of Biochemistry, Faculty of Biotechnology and Biomolecular Sciences, Universiti Putra Malaysia, 43400 UPM \\ Serdang, Selangor, Malaysia.
}

Publication history: Received on 09 January 2019; revised on 28 January 2019; accepted on 29 January 2019

Article DOI: https://doi.org/10.30574/gscbps.2019.6.2.0003

\begin{abstract}
Since ancient civilization, plants have been utilized in many aspects of life, especially in medicinal purposes due to the presence of distinctive secondary metabolites like alkaloids, phenolics and terpenoids. Among them, alkaloids represent a large group of secondary metabolites that have basic properties and comprise nitrogen atom within the heterocyclic ring. Plant synthesizes alkaloids to maintain their survivability under unfavorable conditions. Over 3000 years, indigenous people have been used alkaloid-containing plant extracts to treat several ailments such as fever, snakebite and insanity. However, despite significant benefits to humans and pharmaceutical industries, some of the plant alkaloids are categorized as main plant toxins due to their enormous structural diversity and various modes of actions. Humans and animals can be exposed to toxic alkaloids either through inhalation, swallowing or by direct contact, therefore leads to the specific mechanism that involves receptors, transporters, enzymes and genetic materials at specific cells and tissues, hence may cause hepatotoxic effects and musculoskeletal deformities. This review focuses on some of the plant alkaloids such as pyrrolizidine, tropane, piperidine and indolizidine, which can give various side effects on humans and animals such as itching, nausea, vomiting, mild gastrointestinal perturbation, psychosis, paralysis, teratogenicity, arrhythmias and sudden death.
\end{abstract}

Keywords: Plant toxins; Pyrrolizidine alkaloids; Tropane alkaloids; Piperidine alkaloids; Indolizidine alkaloids

\section{Introduction}

Alkaloids are a group of nitrogen-containing compounds present in plants, fungi, bacteria and animals [1]. The presence of nitrogen atom in the alkaloid structure makes the compound having drug properties. The lone pair electrons on the nitrogen can accept the protons while hydrogen in primary and secondary amine can act as a proton donor [2]. Alkaloids are mostly found in the higher plants, especially in plant root, fruit and stem, which about 31,000 compounds have been identified [3,4]. Papaveraceae (poppies), Ranuncalaceae (buttercups), Solanaceae (nightshades) and Amaryllidaceae (amaryllis) are among plant species that have been recognized to contain high alkaloid content. But, the concentration of alkaloids in these plants varies and always depends on the specific factors such as geographical region and climate [5,6]. Morphine is the first alkaloid isolated from the Papaver somniferum L. (Opium poppy) in 1804 [7]. Afterwards, discovering of several other alkaloids such benzylisoquinoline, papaverine and sanguinarine from P. somniferum makes this plant becomes a model system to investigate alkaloid biosynthesis [8].

Alkaloid-rich plants exhibit a wide range of pharmacological properties such as antibacterial, analgesic [9], antidepressant [10] and anticancer [11]. Also, some of them have been proven to possess neuroprotective properties, therefore they have been used to treat Alzheimer's disease [5, 12]. An interest to exploit alkaloids like pyrrolizidine, indolizidine, piperidine and tropane as pharmaceutical drugs has definitely drawn attention of toxicologists to further understand the alkaloid toxicity levels towards humans and animals. Most of the studies have shown that the structural diversity and various action modes of alkaloids are the main reasons of diverge toxicity effects of different alkaloid

\footnotetext{
${ }^{*}$ Corresponding author

E-mail address: azzreena@upm.edu.my
} 
groups $[13,14]$. Besides, the toxicity effects of alkaloids also depend on specific dosage, exposure time, sensitivity, site of action and developmental stage of organism [15]. Hence, this review focuses on some of the plant-derived alkaloids that give toxic effects on humans and animals.

\section{Functions of alkaloids in plants and animals}

In plants, alkaloids are nitrogen storage compounds that are involved to protect them from predators, and functioned as growth regulators and substitutes for minerals like potassium and calcium [16]. When predators attack plants, the alkaloids can interfere the predator's nervous system, membrane transport, protein synthesis and enzyme activity [17], while under abiotic or biotic stress alkaloids can enhance plant reproductive rates [15]. Some of the alkaloids may also act as herbicide by inhibiting the growth of competing plants $[4,18]$.

The use of alkaloids as a drug in human history has revealed the importance of these compounds in the pharmaceutical industry. For instance, the alkaloid derived from beta-carboline group such as harmine has been used as antimicrobial, anti-HIV and anti-parasitic [19]. The vinca alkaloid (vinblastine and vincristine) isolated from Catharanthus roseus, berberine isolated from Coptis spp. and taxol isolated from Taxus bravifolia have been employed as anticancer drugs for treating leukemias, lymphomas, testicular cancer, breast cancer, lung cancers and Kaposi's sarcoma [3,20-22].

\section{Classification of alkaloids}

Table 1 Classification of alkaloids based on chemical structure

\begin{tabular}{|c|c|c|}
\hline \multirow{2}{*}{\multicolumn{2}{|c|}{$\begin{array}{l}\text { Types of alkaloids } \\
\text { Non-heterocyclic alkaloids }\end{array}$}} & \multirow{2}{*}{$\begin{array}{l}\text { Representative } \\
\text { Hordenine or N-Methyltyramine, Mescaline, Ephedrine, } \\
\text { Colchicine, Erythromycin, Jurubin, Pachysandrine A, Taxol }\end{array}$} \\
\hline & & \\
\hline \multirow{14}{*}{$\begin{array}{l}\text { Heterocyclic } \\
\text { alkaloids }\end{array}$} & Pyrrole and pyrrolidine & Hygrines, Stachydrine \\
\hline & Pyrrolizidine & Symphitine, Echimidine, Senecionine, Seneciphylline \\
\hline & Pyridine and piperidine & $\begin{array}{l}\text { Trigonelline, Coniine, Arecoline, Lobeline, Pelletierine, } \\
\text { Nicotine, Anabasine, Piperine, Ricinine }\end{array}$ \\
\hline & Tropane & $\begin{array}{l}\text { Hyoscyamine, Atropine, Hyoscine, Meteloidine, } \\
\text { Calystegines, Cocaine, Pseudo-pelletierine }\end{array}$ \\
\hline & Quinoline & Quinine, Quinidine, Cinchonine, Cinchonidine, Cusparine \\
\hline & Isoqunoline & $\begin{array}{l}\text { Papaverine, Narceine, Narcotine, Corydaline, Hydrastine, } \\
\text { Berberine, Emetine, Cephaeline, Tubocurarine, Morphine, } \\
\text { Codeine, Erythraline, Galanthamine }\end{array}$ \\
\hline & Aporphine & Boldine \\
\hline & Quinolizidine & Sparteine, Cytisine, Lupanine, Laburnine \\
\hline & Indole or benzopyrrole & $\begin{array}{l}\text { Ergometrine, Ergotamine, Lysergic acid amide, Clavine } \\
\text { Alkaloids, Physostigmine, Ajmaline, Serpentine, Reserpine, } \\
\text { Yohimbine, Aspidospermine, Vinblastine, Vincristine, } \\
\text { Strychnine, Brucine }\end{array}$ \\
\hline & Indolizidine & Castanospermine, Swainsonine \\
\hline & Imidazole or glyoxaline & Pilocarpine \\
\hline & Purine (pyrimidine/imidazole) & Caffeine, Theobromine \\
\hline & $\begin{array}{l}\text { Steroidal (some combined as } \\
\text { glycosides) }\end{array}$ & $\begin{array}{l}\text { Solanidine, Veratrum alkamine esters and their glycosides, } \\
\text { Conessine, Funtumine }\end{array}$ \\
\hline & Terpenoid & Aconitine, Atisine, Lyctonine \\
\hline
\end{tabular}


The molecular complexities of alkaloid structures have caused difficulties in classifying these compounds [23]. However, previous reports have established the different approaches to classify alkaloids like pharmacological action, chemical structure, biochemical origin and taxonomical origin. Among these classification systems, the classification technique based on chemical structure and biochemical origin are the common methods used [1]. Table 1 shows alkaloid classification based on the chemical structure that is further categorized into two divisions, which are non-heterocyclic (protoalkaloids) and heterocyclic (typical alkaloids). The heterocyclic division is further subdivided into 14 groups depending on their ring structure [1].

\section{Toxicity effects of plant alkaloids on animals and humans}

Plants naturally synthesize alkaloid compounds based on their needs. Some of the synthesized alkaloids like hepatotoxic pyrrolizidine, indolizidine, piperidine and tropane have been documented to cause toxic effects on animals and humans [24-25]. These alkaloids may enter human body either through inhalation or swallowing. Further, the traditional medication that needs humans consume alkaloid-containing plants without proper medical prescription is a common way they get intoxicated by toxic alkaloids. For animals, grazing activity is a usual way they obtain these poisonous compounds [25].

The ingested plants containing toxic alkaloids can cause injury to the human body, even though the plant extract is taken in a relatively small amount. This indicates the intoxication response relies on the sensitivity of the target animal [13]. The toxic alkaloids may interfere normal functions of human body systems through specific mechanism that involves receptors, transporters, enzymes and genetic materials at specific cells and tissues [26]. The mild toxic effects of consuming toxic alkaloids are itching, nausea, vomiting and mild gastrointestinal perturbation while the chronic effects are psychosis, paralysis, teratogenicity, arrhythmias and sudden death [13,24]. Hence, we further discuss the properties and toxic effects of some plant alkaloids that have been reported to display toxic effects on humans and animals.

\subsection{Pyrrolizidine alkaloids}

Pyrrolizidine alkaloids (PAs) are ester alkaloids composed of necine and necic acid moieties as illustrated in Figure 1. These alkaloids can be found in families Asteraceae, Boraginaceae and Fabaceae [25, 27]. They are classified as toxic alkaloids owing to the presence of 1,2 double bond at necine moiety. The toxic effects of PAs are generally associated with the exposure time, dosage amount, susceptibility of organisms and the conversion rate of PAs by oxidases. In biological system, the oxidases can covert PAs to reactive pyrroles, which later the product of catalytic reaction can react with nucleic acids and proteins [15, 28]. Examples of PAs are riddelliine, retrosine, monocrotaline, symphytine, lasiocarpine, heliotrine, senkirkine and petasitenine [29-31].

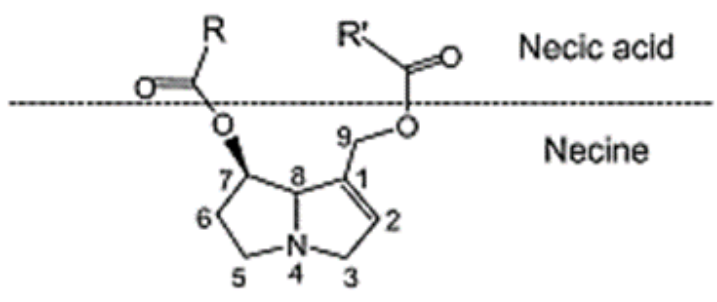

Figure 1 Schematic structure of pyrrolidizine alkaloid [29]

Other than oxidases, liver esterases also take part in the detoxification of PAs. Detoxification failure can cause liver damage (hepatotoxic), which can be indicated by abdominal pain, nausea, vomiting, diarrhea and edema in animals and humans [15, 27]. The esterases can break down PAs ester bond and produce necine and necic acid moieties [32]. Previous researches on rats and guinea pigs further proved the importance of esterases in PAs detoxification process. The rats were reported susceptible to PAs due to lack of esterase activity in liver while guinea pigs showed apparent resistance to PAs due to high liver esterase activity [29]. Table 2 shows the type of PAs that is available in plants and their toxicity effects on humans. 
Table 2 Toxicity effect of pyrrolizidine alkaloids

\begin{tabular}{|c|c|c|c|}
\hline Plants & Pyrrolizidine alkaloids & Toxicity effects & References \\
\hline $\begin{array}{l}\text { Cynoglossum } \\
\text { officinale }\end{array}$ & $\begin{array}{l}\text { 7-Angelylheliotridine, } \\
\text { Echinatine, Acetylheliosupine } \\
\text { and Heliosupine }\end{array}$ & $\begin{array}{l}\text { Anorexia, depression, diarrhea, } \\
\text { photosensitivity, icterus, constipation, } \\
\text { ascites and aberrant behavior }\end{array}$ & [33-34] \\
\hline Senecio spp. & $\begin{array}{l}\text { Seneciphylline, Senecionine, } \\
\text { Jacidine, Jacobine, Jacoline, } \\
\text { Jaconine, Jacozine and } \\
\text { Retrorsine }\end{array}$ & $\begin{array}{l}\text { Hepatic insufficiency, secondary } \\
\text { photosensitization and central nervous } \\
\text { system derangement due to elevated } \\
\text { blood ammonia }\end{array}$ & [34-35] \\
\hline $\begin{array}{l}\text { Senecio } \\
\text { formosus }\end{array}$ & Retrorsine & $\begin{array}{l}\text { Severe veno-occlusive liver disease in } \\
\text { humans }\end{array}$ & [25] \\
\hline $\begin{array}{l}\text { Symphytum } \\
\text { officinale }\end{array}$ & $\begin{array}{l}\text { Lycopsamine, Echimidine and } \\
\text { Lasiocarpine }\end{array}$ & $\begin{array}{l}\text { Produce irreversible hepatic damage if } \\
\text { ingested chronically as an herbal tea }\end{array}$ & [36] \\
\hline
\end{tabular}

\subsection{Tropane alkaloids}

Tropane alkaloids (TAs) (as listed in Table 3) are the common alkaloids found in all plant parts, but the highest contents are determined in roots and seeds of families Brassicaceae, Solanaceae and Erythroxylacea [37]. The TAs production in plants varies depending on plant species and growth location. Over 200 of TAs have been identified, and further subdivided into subgroup according to the number of carbons in the tropane skeleton and stereochemical features [3840]. The most common TAs that can be found in plants are atropine, hyoscyamine and scopolamine (Figure 2) [41].

Table 3 Tropane alkaloids in plants [40, 41]

\begin{tabular}{|c|c|}
\hline Plants & Tropane alkaloids \\
\hline Atropa belladonna & Atropine, Scopolamine, Hyoscyamine \\
\hline Datura stramonium & Atropine, Scopolamine, Hyoscyamine \\
\hline Datura suaveolens & Scopolamine, Hyoscyamine \\
\hline Datura tatula, metel & Atropine \\
\hline Duboisia myoporoides & Atropine, Scopolamine \\
\hline Erycibe henryi & Tropane \\
\hline Hyoscyamus muticus & Scopolamine, Hyoscyamine \\
\hline Hyoscyamus niger & Atropine, Scopolamine, Hyoscyamine \\
\hline Latua pubiflora & Scopolamine, Hyoscyamine \\
\hline Lycium barbarum & Atropine \\
\hline Nicotiana tabacum & Scopolamine, Hyoscyamine \\
\hline Mandragora officinarum & Scopolamine, Hyoscyamine, Atropine \\
\hline Scopolia carniolica Jacq. & Scopolamine, Hyoscyamine, Atropine \\
\hline Hyoscyamus muticus & Scopolamine, Hyoscyamine \\
\hline Nicotiana tabacum & Scopolamine, Hyoscyamine \\
\hline Calystegia sepium & Calystegine \\
\hline Convolvulus arvensis & Calystegine \\
\hline Physalis alkekengi & Calystegine \\
\hline Physalis peruviana & Tigloidine, Secotropane \\
\hline Erythroxylum coca & Many alkaloids including cocaine \\
\hline
\end{tabular}


a)<smiles>O=C(OC1C[C@H]2CC[C@H](C1)C2)C(CO)c1ccccc1</smiles>

b)

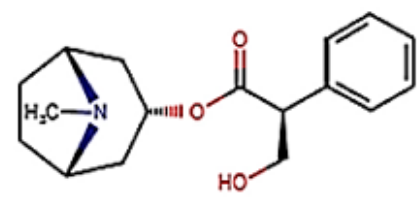

c)

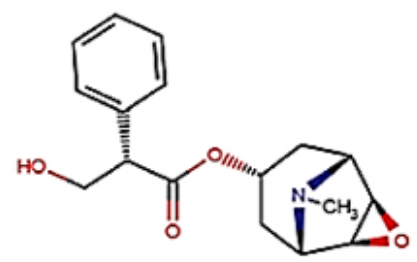

Figure 2 The structure of common tropane alkaloids (TAs) (a) Atropine (b) Hyoscyamine (c) Scopolamine [42]

According to [15], the TA-containing plants have been used by old folks for folkloric and medicinal purposes due to their anticholinergic properties and hallucinogenic effects, which can cause constipation, photophobia, pupil dilatation, vision disturbance, and dryness of upper digestive and respiratory tract mucosa. Exposure to TAs can happen either through direct ingestion of Datura species for their psychoactive properties or indirect ingestion of TA-contaminated foods. The presence of $D$. stramonium in freshly cut hay or maize is usually the source of TAs that causes poisoning incident in horses and cattle [43-45]. But, in low dosage the TAs can be absorbed by gastrointestinal tract and extensively distributed to animal or human tissues, and later excreted from body through urine [40,42].

The pupillary dilation and neurobehavioral consequences are the common toxicological effects occur in experimental animals [46]. In humans, TAs prevent the interaction of acetylcholine to its receptor. This reaction may affect the heart rate, respiration and functions of central nervous system. For example, scopolamine is a competitive antagonist of acetylcholine at both peripheral and central muscarinic receptors [41]. This reaction may lead to the toxicological effects on humans and animals, which for severe cases may lead to the death of both organisms due to respiratory failure [25, 47].

\subsection{Piperidine alkaloids}

Piperidine alkaloids are characterized by a six-membered nitrogen heterocyclic ring [48]. Their toxicity is recognized based on the ability of these compounds to desensitize nicotinic acetylcholine receptors (nAChRs) by targeting the ligand-gated cation channels that mediate the activity of acetylcholine in excitatory neurotransmission [49]. Conium maculatum (Poison Hemlock) is a well-known plant that consists several piperidine alkaloids such as coniine (Figure $3 a)$ and $\gamma$-coniceine (Figure 3b) [24]. According to Diaz [25], coniine was the first alkaloid that chemically synthesized in 1886.

a)<smiles>CCCC1CCCCN1</smiles>

b)

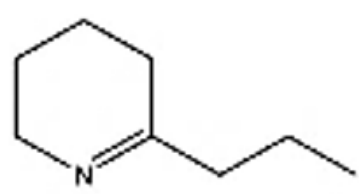

Figure 3 The structure of piperidine alkaloids (a) Coniine (b) $\gamma$-Coniceine [49]

Piperidine alkaloids can give an acute toxic response to the adult livestock animals by causing musculoskeletal deformities. This acute response can be seen through the symptoms of frequent urination and defecation, muscle weakness, tachycardia, ataxia, muscular weakness, collapse and death due to respiratory failure [15]. Green et al. [49] further stated that the teratogenic effects of piperidine alkaloids can lead to multiple congenital contracture deformities and cleft palate in pigs, goats, cattle and sheep. In humans, an accidental consumption of alkaloid containing plants may induce the toxicity symptoms. Herbal medication is a common source of these alkaloids if the medicines are incorrectly prepared or the herb plants are incorrectly used due to misidentification [48]. Table 4 shows the toxicity effects of piperidine alkaloid from different plant species on humans and animals. 
Kamarul Zaman and Mohamad Azzeme / GSC Biological and Pharmaceutical Sciences 2019, 06(02), 021-029

Table 4 Toxicity effects of piperidine alkaloids

\begin{tabular}{llll}
\hline Plants & $\begin{array}{l}\text { Piperidine } \\
\text { compounds }\end{array}$ & Toxicity effects & References \\
\hline Conium maculatum & $\begin{array}{l}\text { Coniine, } \\
\gamma \text {-coniceine }\end{array}$ & $\begin{array}{l}\text { Associated with accidental and deliberate deaths in } \\
\text { humans } \\
\text { Paralysis of the musculature due to the blockade of } \\
\text { the neuromuscular junctions }\end{array}$ & [50] \\
\cline { 2 - 5 } & Conium & $\begin{array}{l}\text { Congenital malformations in calves including cleft } \\
\text { palate and musculoskeletal contractures }\end{array}$ & [24] \\
\hline Equisetum palustre & $\begin{array}{l}\text { Palustrines, } \\
\text { Palustridienes }\end{array}$ & $\begin{array}{l}\text { Unpalatable to cattle due to its high silicate content } \\
\text { Lack of appetite, emaciation, decrease in milk yield } \\
\text { and diarrhea }\end{array}$ & [51] \\
\hline Prosopis juliflora & Juliprosopine, & $\begin{array}{l}\text { Neurotoxic damage in the central nervous system } \\
\text { of cattle and goats }\end{array}$ & [52] \\
\hline
\end{tabular}

\subsection{Indolizidine alkaloids}

Swainsonine (Figure 4) is an indolizidine alkaloid isolated from Swainsona plants [25]. The swainsonine can inhibit lysosomal hydroxylases such as $\alpha$-mannosidase and Golgi $\alpha$-mannosidase, hence leads to the cellular alteration that can be indicated by lysosomal storage disease due to excessive carbohydrate accumulation in lysosomes [53]. Most of the swainsonine poisoning cases are caused by locoweeds species such as Astragalus spp. and Oxytropis spp. [24].

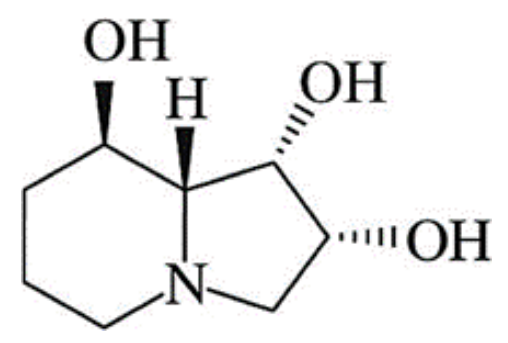

Figure 4 The structure of swainsonine [54]

According to Chenchen et al. [55], ingestion of locoweeds by cattle, sheep and horses can cause the neurological condition called locoism. Apart from that, the swainsonine toxicity may also cause intention tremors, depression, nervousness, proprioceptive deficits, aberrant behavior, emaciation, reproductive dysfunction and death [53, 55]. There are cases of swainsonine poisoning on animals such as a horse where the animal shows a symptom of excitement, exaggerated fright reaction, trembling and mild ataxia [56].

Apart from locoweeds, Ipomoea carnea (batatilla) is one of the plants that accumulates swainsonine, and widely used for hedging $[25,57]$. The plant has been reported to contain toxic alkaloids that can inhibit mannosidase and glycosidase, hence causes lysosomal storage disease in animals. Goats that consumed this plant showed poisoning symptoms such as ataxia, head tremor and nystagmus [57].

\section{Conclusion}

Even though the plant alkaloids have been widely used in the pharmacological especially in the drug discovery, some of these alkaloids show toxicity effects on humans and animals. The precise identification of alkaloid containing plants needs to be done to reduce the poisoning cases. Profiling and identification of toxic alkaloids in plants can definitely help in reducing the risk of taking poisonous plants. Also, the toxicity studies can precisely determine the toxicity level of these alkaloids as well as understand their mode of action in humans and animals. 


\section{Compliance with ethical standards}

\section{Acknowledgments}

The authors wish to thank Universiti Putra Malaysia for funding the Master of Science degree for the principle author under Graduate Research Fellowship (GRF) scheme.

\section{Disclosure of conflict of interest}

The authors declare that there is no conflict of interest.

\section{References}

[1] Cushnie TT, Cushnie B and Lamb AJ. (2014). Alkaloids: an overview of their antibacterial, antibiotic-enhancing and antivirulence activities. International Journal of Antimicrobial Agents, 44(5), 377-386.

[2] Kittakoop P, Mahidol C and Ruchirawat, S. (2014). Alkaloids as important scaffolds in therapeutic drugs for the treatments of cancer, tuberculosis, and smoking cessation. Current Topics in Medicinal Chemistry, 14(2), 239252.

[3] Shi QIU, Hui SUN, Zhang AH, Hong-Ying XU, Guang-Li YAN, Ying HAN and Xi-Jun WANG. (2014). Natural alkaloids: basic aspects, biological roles, and future perspectives. Chinese Journal of Natural Medicines, 12(6), 401-406.

[4] Vanderplanck M and Glauser G. (2018). Integration of non-targeted metabolomics and automated determination of elemental compositions for comprehensive alkaloid profiling in plants. Phytochemistry, 154, 1-9.

[5] Ng YP, Or TCT and Ip NY. (2015). Plant alkaloids as drug leads for Alzheimer's disease. Neurochemistry International, 89, 260-270.

[6] Robertson LP, Hall CR, Forster PI and Carroll AR. (2018). Alkaloid diversity in the leaves of Australian Flindersia (Rutaceae) species driven by adaptation to aridity. Phytochemistry, 152, 71-81.

[7] Dias DA, Urban S and Roessner U. (2012). A historical overview of natural products in drug discovery. Metabolites, 2(2), 303-336.

[8] Beaudoin GA and Facchini PJ. (2014). Benzylisoquinoline alkaloid biosynthesis in opium poppy. Planta, 240(1), 19-32.

[9] Wadood A, Ghufran M, Jamal SB, Naeem M, Khan A and Ghaffar R. (2013). Phytochemical analysis of medicinal plants occurring in local area of Mardan. Biochemistry and Analytical Biochemistry, 2(4), 1-4.

[10] Hamid HA, Ramli ANM and Yusoff MM. (2017). Indole alkaloids from plants as potential leads for antidepressant drugs: a mini review. Frontiers in Pharmacology, 8, 1-7.

[11] Lu JJ, Bao JL, Chen XP, Huang M and Wang YT. (2012). Alkaloids isolated from natural herbs as the anticancer agents. Evidence-based Complementary and Alternative Medicine, 2012, 1-12.

[12] Kurmukov AG. (2013). Phytochemistry of Medicinal Plants. In Medicinal Plants of Central Asia: Uzbekistan and Kyrgyzstan. Springer: New York, 13-14.

[13] Sekhar CJ, Sandhya S, Ravindran V, Banji D, Sudhakar K and Chaitanya RSNAKK. (2012). Plant toxins-useful and harmful effects. Hygeia Journal of Drug and Medicine, 4(1), 79-90.

[14] Perviz S, Khan H and Pervaiz A. (2016). Plant alkaloids as an emerging therapeutic alternative for the treatment of depression. Frontiers in Pharmacology, 7, 1-7.

[15] Matsuura HN and Fett-Neto AG. (2015). Plant alkaloids: main features, toxicity, and mechanisms of action. In Plant Toxins. Springer Netherlands, 1-15.

[16] Waller GR and Nowacki EK. (1978). The role of alkaloids in plants. In: Alkaloid biology and metabolism in plants. Springer: Boston, 143-181

[17] Mazid M, Khan TA, and Mohammad F. (2011). Role of secondary metabolites in defense mechanisms of plants. Biology and Medicine, 3, 232-249.

[18] Muzquiz M, de la Cuadra C, Cuadrado C, Burbano C and Calvo, R. (1994). Herbicide-like effect of Lupinus alkaloids. Industrial Crops and Products, 2(4), 273-280. 
Kamarul Zaman and Mohamad Azzeme / GSC Biological and Pharmaceutical Sciences 2019, 06(02), 021-029

[19] Patel K, Gadewar M, Tripathi R, Prasad SK and Patel DK. (2012). A review on medicinal importance, pharmacological activity and bioanalytical aspects of beta-carboline alkaloid "Harmine". Asian Pacific Journal of Tropical Biomedicine, 2(8), 660-664.

[20] Mohan K, Jeyachandran R and Deepa (2012). Alkaloids as anticancer agents. Annals of Phytomedicine, 1, 46 -53.

[21] Moudi M, Go R, Yien CYS, and Nazre M. (2013). Vinca alkaloids. International Journal of Preventive Medicine, 4, 1231.

[22] Isah T. (2016). Anticancer alkaloids from trees: Development into drugs. Pharmacognosy Reviews, 10(20), 9099.

[23] Saxena M, Saxena J, Nema R, Singh D, and Gupta A. (2013). Phytochemistry of medicinal plants. Journal of Pharmacognosy and Phytochemistry. 1, 168-182.

[24] Cortinovis C and Caloni F. (2015). Alkaloid-containing plants poisonous to cattle and horses in Europe. Toxins, 7(12), 5301-5307.

[25] Diaz GJ. (2015). Toxicosis by plant alkaloids in humans and animals in Colombia. Toxins, 7(12), 5408-5416.

[26] Patel S, Nag MK, Daharwal SJ, Singh MR and Singh D. (2013). Plant Toxins: An Overview. Research Journal of Pharmacology and Pharmacodynamics (RJPPD), 5, 283-288.

[27] Griffin CT, Danaher M, Elliott CT, Kennedy DG and Furey A. (2013). Detection of pyrrolizidine alkaloids in commercial honey using liquid chromatography-ion trap mass spectrometry. Food Chemistry, 136(3-4), 15771583.

[28] Neuman MG and Steenkamp V. (2009). Toxicity profile of pyrrolizidine alkaloid-containing medicinal plants: Emphasis on Senecio species. International Journal of Biomedical and Pahrmaceutical Sciences, 3, $104-108$.

[29] Chen T, Mei N and Fu PP. (2010). Genotoxicity of pyrrolizidine alkaloids. Journal of Applied Toxicology, 30(3), 183-196.

[30] Wiedenfeld H. (2011). Plants containing pyrrolizidine alkaloids: toxicity and problems. Food Additives and Contaminants: Part A, 28(3), 282-292.

[31] Seremet OC, Olaru OT, Gutu CM, Nitulescu GM, Ilie M, Negres S, Zbarcea CE, Purdel CN, Spandidos DA, Tsatsakis AM, Coleman MD, Margina DM. (2018). Toxicity research of certain plant extracts containing pyrrolizidine alkaloids using alternative invertebrates models. Molecular Medicine Reports, 17(6), 7757-7763.

[32] Fu PP, Xia Q, Lin G, Chou MW. (2004). Pyrrolizidine alkaloids - genotoxicity, metabolism, enzymes, metabolic activation and mechanisms. Drug Metabolism Reviews, 36(1), 1-55.

[33] Pfister JA, Molyneux RJ, Baker DC. (1992). Pyrrolizidine alkaloid content of houndstongue (Cynoglossum officinale L.). Journal of Range Management, 45(3), 254-256.

[34] Panter KE, Gardner DR, Lee ST, Pfister JA, Ralphs MH, Stegelmeier BL, James LF. (2012). Important poisonous plants of the United States. In: Gupta RC (Eds), Veterinary Toxicology: Basic and Clinical Principles. Elsevier Inc, San Diego, 1021-1079

[35] Crews C and Anderson WAC. (2009). Detection of ragwort alkaloids in toxic hay by liquid chromatography/timeof-flight mass spectrometry. Veterinary Record, 165(19), 568-569.

[36] Araújo LU, Reis PG, Barbosa LCO, Saúde-Guimarães DA, Grabe-Guimarães S, Mosqueira VCF, Carneiro CM, SilvaBarcellos NM. (2012). In vivo wound healing effects of Symphytum officinale L. leaves extract in different topical formulations. Pharmazie, 67(4), 355-360.

[37] Arcella D and Altieri A. (2018). Human acute exposure assessment to tropane alkaloids. EFSA Journal, 16(2), 5160-5184.

[38] Alexander J. (2008). Tropane alkaloids (from Datura sp.) as undesirable substances in animal feed. EFSA Journal, 691(8), 1-55.

[39] Springob K and Kutchan TM. (2009). Introduction to the different classes of natural products. In Plant-Derived Natural Products. Springer, New York, 3-50

[40] Adamse P, Van Egmond HP, Noordam MY, Mulder PPJ and De Nijs M. (2014). Tropane alkaloids in food: poisoning incidents. Quality Assurance and Safety of Crops and Foods, 6(1), 15-24. 
[41] Adamse P and Van Egmond HP. (2010). Tropane alkaloids in food. RIKILT-Institute of Food Safety: Netherland, 1-24.

[42] Chan TY. (2017). Worldwide occurrence and investigations of contamination of herbal medicines by tropane alkaloids. Toxins, 9(9), 284-293.

[43] Binev R, Valchev I and Nikolov J. (2006). Clinical and pathological studies on intoxication in horses from freshly cut Jimson weed (Datura stramonium)-contaminated maize intended for ensiling: clinical communication. Journal of the South African Veterinary Association, 77(4), 215-219.

[44] Soler-Rodríguez F, Martín A, García-Cambero JP, Oropesa AL and Pérez-López M. (2006). Datura stramonium poisoning in horses: a risk factor for colic. Veterinary Record. 158(4), 132-133.

[45] Bofill FX, Bofill J, Such G, Piqué E and Guitart R. (2007). Two cases of corn contamination poisoning with Datura stramonium in cattle. Toxicology Journal, 24(1), 56-58.

[46] Mulder PP, Nijs M, Castellari M, Hortos M, MacDonald S, Crews C, Hajslova J and Stranska M. (2016). Occurrence of tropane alkaloids in food. EFSA Supporting Publications, 13(12), 1140-1340.

[47] Koleva II, van Beek TA, Soffers AE, Dusemund B and Rietjens IM. (2012). Alkaloids in the human food chainnatural occurrence and possible adverse effects. Molecular Nutrition and Food Research, 56(1), 30-52.

[48] Hotti H and Rischer H. (2017). The killer of Socrates: coniine and related alkaloids in the plant kingdom. Molecules, 22(11), 1962-1985.

[49] Green BT, Lee ST, Panter KE and Brown DR. (2012). Piperidine alkaloids: human and food animal teratogens. Food and chemical toxicology, 50(6), 2049-2055.

[50] Fernández-Alonso JL, Bonilla AG and Idrobo JM. (2007). The plants as legal evidence. Development of forensic botany in Colombia. Journal of the Colombian Academy of Exact, Physical and Natural Sciences, 31, $181-198$.

[51] Cramer L, Ernst L, Lubienski M, Papke U, Schiebel HM, Jerz G and Beuerle T. (2015). Structural and quantitative analysis of Equisetum alkaloids. Phytochemistry, 116, 269-282.

[52] da Silva VDA, da Silva AMM, e Silva JHC and Costa SL. (2018). Neurotoxicity of Prosopis juliflora: from Natural Poisoning to Mechanism of Action of Its Piperidine Alkaloids. Neurotoxicity Research, 34(4), 878-888.

[53] Wu C, Feng K, Lu D, Yan D, Han T and Zhao B. (2016). Reproductive Toxicities Caused by Swainsonine from Locoweed in Mice. BioMed Research International, 2016, 1-9.

[54] Lu H, Zhang L, Wang S, Wang W and Zhao B. (2013). The study of the oxytropis kansuensis-induced apoptotic pathway in the cerebrum of SD rats. BMC Veterinary Research, 9(1), 217-222.

[55] Chenchen W, Wenlong W, Xiaoxue L, Feng M, Dandan C, Xiaowen Y and Baoyu Z. (2014). Pathogenesis and preventive treatment for animal disease due to locoweed poisoning. Environmental toxicology and pharmacology, 37(1), 336-347.

[56] Nollet H, Panter K, Vanschandevijl K, Lefere L, Stegelmeier B and Deprez P. (2008). Suspected swainsonine poisoning in a Belgian horse. Equine Veterinary Education, 20(2), 62-65.

[57] Botha CJ and Penrith ML. (2008). Poisonous plants of veterinary and human importance in southern Africa. Journal of Ethnopharmacology, 119(3), 549-558.

\section{How to cite this article}

Kamarul Zaman MA and Azzeme AM. (2019). Plant toxins: alkaloids and their toxicities. GSC Biological and Pharmaceutical Sciences, 6(2), 21-29. 